Volume 1 Nomor 2, Agustus 2016, halaman 149-162

\title{
PENGARUH MOTIVASI DAN KEBIASAAN BELAJAR SISWA TERHADAP HASIL BELAJAR MATEMATIKA
}

\author{
Rosyadi \\ Universitas Wiralodra, rosrosyadi@yahoo.co.id
}

\begin{abstract}
ABSTRAK
Penelitian ini bertujuan untuk mengetahui (1) pengaruh positif motivasi belajar siswa terhadap hasil belajar matematika; (2) pengaruh positif kebiasaan belajar siswa terhadap hasil belajar matematika; dan (3) pengaruh positif antara motivasi dan kebiasaan belajar siswa secara bersama-sama terhadap hasil belajar matematika. Penelitian dilakukan dengan menggunakan metode survey eksplanasi. Pada penelitian ini terdapat tiga instrumen. Instrumen hasil belajar matematika berbentuk tes uraian. Sedangkan instrumen motivasi dan kebaisaan belajar siswa berupa angket atau kuesioner. Teknik analisis data yang digunakan dalam penelitian ini adalah analisis regresi sederhana dan regresi berganda. Berdasarkan hasil analisis, diperoleh kesimpulan: (1) terdapat pengaruh positif motivasi belajar siswa terhadap hasil belajar matematika; (2) terdapat pengaruh positif kebiasaan belajar siswa terhadap hasil belajar matematika; dan (3) terdapat pengaruh positif motivasi dan kebiasaan belajar siswa secara bersama-sama terhadap hasil belajar matematika.
\end{abstract}

Kata Kunci: Pengaruh, Motivasi, Kebiasaan Belajar, Hasil Belajar Matematika.

\section{ABSTRACT}

This research aims to determine: (1) a positive influence of student's motivation towards their mathematics learning outcomes; (2) a positive influence of student's learning habits towards mathematics learning outcomes; (3) and a positive influence of the student's between motivation and study habits combined toward mathematics learning outcomes. The research was conducted using a survey method explanation. In this research, there are three instruments. The instrument for the student's mathematics learning outcomes is in essay form. While the instrument for student's motivation and study habits are in the form of questionnaires. Data analysis technique used in this research is simple regression and double regression. Based on the analysis, it can be concluded that: (1) there is a positive influence of the student's motivation towards their mathematics learning outcomes; (2) there is a positive influence of the student's study habits towards their learning outcomes; and (3) there is a positive influence motivation and study habits of students combined toward their outcomes in learning mathematics.

Keywords: Influence, Motivation, Learning

Habit,

Mathematics

Achievement.

How to Cite: Rosyadi. (2016). Pengaruh Motivasi dan Kebiasaan Belajar Siswa Terhadap Hasil Belajar Matematika. Mathline: Jurnal Matematika dan Pendidikan Matematika, Vol.1, No.2, 149-162. 


\section{PENDAHULUAN}

Majunya suatu bangsa dipengaruhi oleh mutu pendidikan dari bangsa itu sendiri karena pendidikan dapat mencetak Sumber Daya Manusia (SDM) yang berkualitas. Salah satu cara meningkatkan dan mengembangkan kualitas SDM adalah dengan jalan meningkatkan mutu pendidikan, karena pendidikan merupakan salah satu ujung tombak penentu kemajuan suatu bangsa. Soetopo dan Soemanto (1988) mengatakan bahwa masalah pendidikan merupakan masalah yang tidak dapat dilepaskan dari kehidupan baik kehidupan keluarga, bangsa, dan negara. Kemajuan suatu bangsa atau negara sebagian ditentukan oleh maju mundurnya pendidikan negara tersebut. Pendidikan yang dimaksud adalah pendidikan formal, yaitu proses belajar mengajar di sekolah. Matematika merupakan mata pelajaran yang penting untuk dipelajari. Hampir semua aspek kehidupan berkaitan dengan matematika. Misalnya melakukan jual beli, mengukur luas tanah pekarangan, areal sawah, menimbang beras, menghitung pengeluaran kebutuhan rumah tangga, menghitung biaya pembayaran rekening listrik, membayar hutang dan sebagainya. Selain itu, matematika juga berperan pada bidang keilmuan lainnya diantaranya fisika, ekonomi, dan biologi.

Mengingat pentingnya ilmu matematika, maka sangat diharapkan siswa dapat memahami matematika secara menyeluruh agar hasil belajar matematika siswa maksimal. Kenyataannya banyak siswa yang tidak menyukai pelajaran matematika. Keluhan yang sering terjadi pada siswa dalam matematika adalah penggunaan rumus-rumus dan kesulitan menyelesaikan soal ketika mendapatkan soal yang kondisi soalnya berbeda dengan contoh soal sebelumnya. Banyak faktor yang menyebabkan rendahnya hasil belajar matematika, faktor yang mempengaruhi hasil belajar siswa terdiri dari dua faktor, yaitu faktor yang berasal dari dalam diri siswa (intern) dan faktor yang berasal dari luar diri siswa (ekstern). Menurut Siregar \& Nara (2014) bahwa, faktor-faktor yang berasal dari dalam diri siswa diantaranya adalah kesehatan, rasa aman, faktor kemampuan intelektual, faktor afektif seperti perasaan dan percaya diri, motivasi, kematangan untuk belajar, usia, jenis kelamin, latar belakang sosial, kebiasaan belajar, kemampuan mengingat, kemapuan pengindraan seperti melihat, mendengar atau merasakan. Sedangkan faktor-faktor yang berasal dari luar diri siswa diantaranya adalah (1) faktor sosial, faktor sosial diantaranya adalah (a) lingkungan keluarga, meliputi: orang tua, susasana rumah, kemampuan ekonomi keluarga, latar belakang kebudayaan. (b) lingkungan sekolah, meliputi: interaksi guru dan murid, hubungan antar murid, cara penyajian bahan pelajaran. (c) lingkungan masyarakat, meliputi: teman bergaul, 
pola hidup lingkungan, kegiatan dalam masyarakat; (2) faktor non sosial, diantaranya adalah (a) sarana dan prasarana sekolah, meliputi: kurikulum, media pendidikan, keadaan gedung, sarana belajar. (b) waktu belajar (c) rumah (d) alam. Di antara faktor-faktor di atas, yang paling banyak ditemui adalah motivasi belajar siswa yang rendah. Rendahnya motivasi belajar siswa dapat terlihat dari proses belajar mengajar dan hasil belajar mereka di kelas. Siswa cenderung bermalas-malasan, melamun, dan lalai dalam melaksanakan tugas-tugas yang diberikan oleh gurunya. Sehingga, mengakibatkan hasil belajar matematika siswa rendah.

Selain motivasi belajar, hal yang dapat mempengaruhi rendahnya hasil belajar matematika adalah kebiasaan belajar. Kebiasaan belajar turut pula memainkan peranan yang sangat penting bagi para siswa untuk memperoleh hasil belajar yang maksimal. Kecerdasan tidak dianggap sebagai faktor utama untuk mencapai sukses dalam belajar, tetapi intelegensi yang tinggi jika didukung kebiasaan belajar yang baik dan dilandasi motivasi belajar yang kuat pasti akan medatangkan sukses dalam belajar. Kebiasaan belajar siswa banyak dipengaruhi lingkungan dimana siswa itu berada seperti lingkungan keluarga, sekolah, dan masyarakat di sekitarnya. Siswa yang dibesarkan di keluarga yang memiliki kebiasaan belajar yang baik cenderung akan memiliki kebiasaan belajar yang baik pula. Begitupun lingkungan sekolah yang kondusif akan berpengaruh terhadap kebiasaan belajar siswa. Siswa yang telah memiliki kebiasaan belajar yang baik maka mereka akan belajar dengan sebaik mungkin dengan persiapan yang matang dan dilakukan secara rutin. Tetapi, bagi sebagian siswa yang memiliki kebiasaan belajar yang tidak baik, siswa belajar hanya pada saat menjelang ujian bahkan kadang tanpa ada persiapan sama sekali. Tujuan dari penelitian ini adalah sebagai berikut (1) untuk mengetahui pengaruh positif motivasi belajar siswa terhadap hasil belajar matematika; (2) untuk mengetahui pengaruh positif kebiasaan belajar siswa terhadap hasil belajar matematika; (3) Untuk mengetahui pengaruh positif motivasi dan kebiasaan belajar siswa secara bersama-sama terhadap hasil belajar matematika.

\section{METODE PENELITIAN}

Penelitian ini dilaksanakan di SMP Negeri 2 Sindang yang beralamatkan di Jl. Murah Nara no. 5 Kecamatan Sindang Kabupaten Indramayu Telp (0234) 272032. Penelitian dilaksanakan pada semester genap Tahun Pelajaran 2014/2015. Populasi penelitian kelas VIII yang berjumlah 306 siswa. Menurut Sugiyono (2012), sampel adalah bagian dari jumlah dan 
karakteristik yang dimiliki oleh pupulasi tersebut. Jadi sampel merupakan bagian dari populasi dan memiliki karakteristik yang dimiliki oleh populasi. Karena siswa tiap kelas VIII di SMP Negeri 2 Sindang adalah heterogen maka untuk menentukan anggota sampel dari tiap-tiap stratum dengan cara random kelas. Sampel yang diambil dalam penelitian ini berjumlah 173 siswa, jumlah sampel tiap kelas sebanyak 19 siswa. Jumlah sampel dari tiap cluster mempunyai peluang yang sama untuk dipilih. Pemilihan sampel dilakukan dengan cara undian yang setiap anggota per kelas diberi nomor terlebih dahulu.

Nazir (2011) mengemukakan bahwa disain penelitian adalah semua proses yang diperlukan dalam perencanaan dan pelaksanaan penelitian. Metode penelitian yang digunakan dalam penelitian ini adalah metode survey eksplanasi. Menurut Effendi \& Tukiran (2012) bahwa metode survey eksplanasi yakni untuk menjelaskan hubungan kausal antar variabel melalui pengujian hipotesis. Lain halnya Faisal (2007) mengemukakan bahwa, Penelitian eksplanasi yaitu suatu penelitian yang dimaksudkan untuk menemukan dan mengembangkan teori, sehingga hasil atau produk penelitiannya dapat menjelaskan kenapa atau mengapa (variabel anteseden apa saja yang mempengaruhi) terjadinya sesuatu gejala atau kenyataan sosial tertentu.

Teknik pengumpulan data yang digunakan dalam penelitian ini adalah dengan menggunakan kuesioner dan tes. Dalam penelitian ini, peneliti menyebar angket motivasi dan kebiasaan belajar siswa serta memberikan tes hasil belajar matematika kepada sampel yang terpilih. Desain penelitian dalam penelitian ini adalah sebagai berikut:

\section{$\mathrm{R}: \mathrm{O}_{1} \mathrm{O}_{2} \mathrm{O}_{3}$}

\section{Keterangan:}

$\mathrm{R}$ : Random untuk menentukan sampel.

O1: Observasi 1 ( Angket untuk motivasi belajar)

$\mathrm{O}_{2}$ : Observasi 2 ( Angket untuk kebiasaan belajar)

O3: Observasi 3 ( Tes untuk hasil belajar matematika)

Menurut Arikunto (2012) instrumen penelitian merupakan alat atau fasilitas yang digunakan oleh peneliti dalam mengumpulkan data agar pekerjaannya lebih mudah dan hasilnya lebih baik, dalam arti lebih cermat, lengkap, dan sistematis sehingga lebih mudah diolah. Terdapat tiga instrumen dalam penelitian ini, yaitu instrumen untuk mengukur hasil belajar matematika, instrumen untuk mengukur motivasi belajar siswa dan instrumen untuk mengukur kebiasaan belajar siswa. Instrumen yang digunakan untuk mengukur hasil belajar 
matematika berbentuk tes soal uraian yang terdiri dari 6 soal uraian dengan skor total 77, skor minimal 0 dan maksimal ideal 77. Instrumen yang digunakan untuk mengukur motivasi dan kebiasaan belajar matematika menggunakan kuesioner atau angket yang dimodifikasi dari angket skala sikap (skala Likert). Angket motivasi belajar matematika terdapat 15 butir soal pernyataan dengan skor maksimal 75. Sedangkan untuk angket kebiasaan belajar matematika terdapat 23 butir soal pernyataan dengan skor maksimal 115. Selain itu, kuesioner atau angket ini dibagi menjadi dua jenis pernyataan yaitu kuesioner atau angket dengan pernyataan positif dan pernyataan negatif.

Dalam penelitian ini penulis menggunakan kuesioner atau angket tertutup yang dimodifikasi dari angket skala sikap (Skala Likert) sebagai instrumen untuk mengukur motivasi dan kebiasaan belajar siswa. Menurut Sugiyono (2012), skala likert digunakan untuk mengukur sikap, pendapat, dan persepsi seseorang atau sekelompok orang tentang fenomena sosial. Disamping itu, menurut Arikunto (2012), instrumen yang baik harus memenuhi dua persyaratan penting yaitu valid dan reliabel. Instrumen dikatakan valid jika instrumen tersebut mengukur apa yang seharusnya diukur. Secara garis besar validitas dibagi menjadi dua, yaitu validitas logis dan validitas empiris. Dalam hal ini untuk validitas logis instrumen hasil belajar matematika berupa validitas isi. Validitas isi diperoleh dengan cara membandingkan isi instrumen dengan materi pelajaran yang diajarkan yang sesuai kompetensi dasar yang tertera dalam kurikulum. Untuk validitas logis instrumen motivasi dan kebiasaan belajar matematika berupa validitas konstruk. Validitas ini diperoleh dengan cara merinci dan memasangkan setiap butir pernyataan dengan setiap aspek atau domain berdasarkan tujuan yang hendak dicapai. Selain itu, instrumen yang telah disusun berdasarkan teori penyusunan instrumen secara teoritis sudah sesuai dengan kisi-kisi instrumen dan adanya validasi dari pakar, yaitu melalui konsultasi dengan dosen dan guru mata pelajaran matematika di tempat penulis melakukan penelitian.

\section{HASIL DAN PEMBAHASAN}

Data hasil penelitian meliputi skor angket motivasi belajar siswa (X1), skor angket kebiasaan belajar siswa $\left(\mathrm{X}_{2}\right)$, dan skor tes hasil belajar matematika (Y). Berdasarkan tes hasil belajar matematika yang didapat dari seluruh sampel penelitian yang berjumlah 173 siswa diperoleh skor maksimal sebesar 77 dan skor minimal 12. Rata-rata ideal dan standar deviasi 
ideal masing-masing adalah sebesar 44,5 dan 10,83. Berdasarkan perhitungan skor tes hasil belajar matematika dengan kriteria deskripsi di atas, diperoleh hasil dalam Tabel 1 berikut:

Tabel 1. Hasil Skor Tes Hasil Belajar Matematika

\begin{tabular}{cccc}
\hline Interval & Kriteria & Frekuensi & Prosentase \\
\hline$X i<33,67$ & Rendah & 25 & $14,45 \%$ \\
$33,67 \leq X i<55,33$ & Sedang & 29 & $16,76 \%$ \\
$X i \geq 55,33$ & Tinggi & 119 & $68,79 \%$ \\
& Jumlah & 173 & $100 \%$ \\
\hline
\end{tabular}

Berdasarkan hasil angket motivasi belajar siswa yang didapat dari seluruh sampel penelitian yang berjumlah 173 siswa diperoleh skor maksimal sebesar 75 dan skor minimal 15. Ratarata ideal dan standar deviasi ideal masing-masing adalah sebesar 45 dan 10. Berdasarkan perhitungan skor angket dengan kriteria deskripsi di atas, diperoleh hasil dalam Tabel 2 berikut:

Tabel 2. Hasil Skor Motivasi Belajar Matematika Siswa

\begin{tabular}{cccc}
\hline Interval & Kriteria & Frekuensi & Prosentase \\
\hline$X i<35$ & Rendah & 24 & $13,87 \%$ \\
$35 \leq X i<55$ & Sedang & 24 & $13,87 \%$ \\
$X i \geq 55$ & Tinggi & 125 & $72,25 \%$ \\
& Jumlah & 173 & $100 \%$ \\
\hline
\end{tabular}

Berdasarkan hasil angket kebiasaan belajar yang didapat dari seluruh sampel penelitian yang berjumlah 173 siswa diperoleh skor maksimal sebesar 105 dan skor minimal 23 dengan ratarata ideal sebesar 64. Berdasarkan perhitungan skor angket dengan kriteria deskripsi di atas, diperoleh hasil dalam Tabel 3 berikut:

Tabel 3. Hasil Skor Angket Kebiasaan Belajar Matematika Siswa

\begin{tabular}{|c|c|c|c|}
\hline Interval & Kriteria & Frekuensi & Prosentase \\
\hline$X i>64$ & Baik & 110 & $63,58 \%$ \\
\hline$X i \leq 64$ & Tidak Baik & 63 & $36,42 \%$ \\
\hline \multicolumn{2}{|c|}{ Jumlah } & 173 & $100 \%$ \\
\hline
\end{tabular}




\section{Pengaruh Motivasi Belajar Siswa (X1) terhadap Hasil Belajar Matematika (Y)}

Berdasarkan hasil perhitungan analisis regresi linear sederhana mengenai pengaruh motivasi belajar siswa $\left(\mathrm{X}_{1}\right)$ terhadap hasil belajar matematika $(\mathrm{Y})$ diperoleh nilai konstanta $a$ $=0,05$ dan koefisien $b=0,97$. Sehingga persamaan regresinya adalah $Y^{\wedge}=0,04+0,97 X$. Selanjutnya dilakukan uji linieritas dan uji signifikansi dengan menggunakan analisis varian dengan hasil dalam Tabel 4 sebagai berikut.

Tabel 4. Hasil Anava Untuk Persamaan Regresi $\bar{Y}=0,04+0,97 X$

\begin{tabular}{lllllll}
\hline $\begin{array}{l}\text { Sumber } \\
\text { Varians }\end{array}$ & \multicolumn{1}{c}{$\mathbf{~ J K}$} & \multicolumn{1}{c}{$\mathbf{d b}$} & \multicolumn{1}{c}{ RJK } & $F_{\text {hitung }}$ & $F_{\text {Tabelo }=0,05}$ & Keterangan \\
\hline Total & 626978 & 173 & & & & \\
Reg (a) & 560140,67 & 1 & 560140,67 & & & \\
Reg (bla) & 57845,57 & 1 & 57845,57 & 1100,14 & 3,89 & Signifikan \\
Sisa & 8991,76 & 171 & 52,58 & & & \\
Tuna Cocok & 4,5 & 37 & 0,12 & 0,002 & 1,49 & Linear \\
Galat & 8987,26 & 134 & 67,07 & 0,007 & \\
\hline
\end{tabular}

Berdasarkan Tabel 4. pada pengujian signifikansi regresi diperoleh $F$ hitung $=1100,14$ dan $F_{(0,95 ; 1 ; 171)}=3,89$ karena $F_{\text {hitung }}>F_{(0,95 ; 1 ; 171)}$ yaitu 1100,14 > 3,89 maka tolak Ho. Artinya, regresi hasil belajar matematika atas motivasi belajar siswa adalah signifikan. Sedangkan pada pengujian linearitas regresi diperoleh $F_{\text {hitung }}=0,002$ dan $F_{(0,95 ; 37 ; 134)}=1,49$ karena $F_{\text {hitung }}$ $<F(0,95 ; 37 ; 134)$ yaitu $0,002<1,49$ maka terima $\mathrm{H}_{0}$. Artinya, regresi hasil belajar matematika atas motivasi belajar siswa adalah linear. Dengan demikian persamaan regresi dapat digunakan untuk memprediksi hasil belajar matematika.

Selanjutnya, mencari nilai koefisien korelasi. Berdasarkan perhitungan, diperoleh nilai koefisien korelasi $r_{X Y}=0,93$. Setelah diuji signifikansinya dengan menggunakan statistik uji-t diperoleh thitung $=32,86$ dan $t$ tabel $=1,65$ karena thitung $>$ t tabel yaitu 32,86 $>1,65$ maka tolak Ho. Artinya, korelasi antara motivasi belajar siswa dan hasil belajar matematika adalah signifikan. Karena koefisien korelasi bernilai positif, maka dapat dikatakan bahwa koefisien korelasi antara motivasi belajar siswa dan hasil belajar matematika bersifat positif dan signifikan. Hal ini berarti semakin tinggi motivasi belajar siswa maka semakin tinggi pula hasil belajar matematika. Selanjutnya guna mengetahui seberapa besar sumbangan relatif atau kontribusi dari variabel motivasi belajar siswa terhadap hasil belajar matematika maka akan dicari koefisien determinasinya. Berdasarkan perhitungan diperoleh nilai koefisien determiasi $(r 2)=0,8649$. Koefisien determinasi ini ditentukan dengan mengkuadratkan nilai koefisien 
korelasi dan dikalikan dengan $100 \%$. Sehingga konstribusi variabel $\mathrm{X}_{1}$ terhadap Y sebesar $86,49 \%$. Angka ini berarti sebesar $86,49 \%$ hasil belajar matematika dapat dijelaskan dengan menggunakan variabel motivasi belajar siswa. Sedangkan 13,51\% dipengaruhi oleh faktor lain. Berdasarkan hasil uji tersebut, dapat disimpulkan bahwa terdapat pengaruh positif motivasi belajar siswa terhadap hasil belajar matematika.

\section{Pengaruh Kebiasaan Belajar Siswa (X2) terhadap Hasil Belajar Matematika (Y)}

Berdasarkan hasil perhitungan analisis regresi linear sederhana mengenai pengaruh kebiasaan belajar siswa $\left(\mathrm{X}_{2}\right)$ terhadap hasil belajar matematika $(\mathrm{Y})$ diperoleh nilai konstanta $\alpha=15,99$ dan koefisien $b=0,62$, sehingga persamaan regresinya adalah $Y^{\wedge}=15,99+$ $0,62 X$. Selanjutnya dilakukan uji linieritas dan uji signifikansi dengan menggunakan analisis varian regresi yang disajikan pada Tabel 5 .

Tabel 5. Hasil Anava Untuk Persamaan Regresi $\bar{Y}=15,99+0,62 X$

\begin{tabular}{llllllc}
\hline $\begin{array}{l}\text { Sumber } \\
\text { Varians }\end{array}$ & \multicolumn{1}{c}{$\mathbf{J K}$} & $\mathbf{d b}$ & \multicolumn{1}{c}{ RJK } & $F_{\text {hitung }}$ & $F_{\text {Tabelo }=0,05}$ & Keterangan \\
\hline Total & 626978 & 173 & & & & \\
Reg (a) & 560140,67 & 1 & 560140,67 & & & \\
Reg (bla) & 48615,32 & 1 & 48615,32 & 456,22 & 3,89 & Signifikan \\
Sisa & 18222,01 & 171 & 106,56 & & & \\
Tuna Cocok & 6429,45 & 61 & 107,21 & 0,98 & 1,44 & Linear \\
Galat & 11792,56 & 110 & 105,40 & & & \\
\hline
\end{tabular}

Berdasarkan Tabel 5, pada pengujian signifikansi regresi diperoleh $F_{\text {hitung }}=456,22$ dan $F_{\text {tabel }}$ $=3,89$ karena $F_{\text {hitung }}>F_{\text {tabel }}$ yaitu, 456,22 > 3,89 maka tolak Ho. Artinya, regresi hasil belajar matematika atas kebiasan belajar siswa adalah signifikan. Sedangkan pada pengujian linearitas regresi diperoleh $F_{\text {hitung }}=0,98$ dan $F_{\text {tabel }}=1,44$ karena $F_{\text {hitung }} \leq F_{\text {tabel }}$ yaitu, 0,98 $\leq$ 1,44 maka terima $\mathrm{H}_{0}$. Artinya, regresi hasil belajar matematika atas motivasi belajar siswa adalah linear. Selanjutnya, mencari nilai koefisien korelasi. Berdasarkan perhitungan, diperoleh nilai koefisien korelasi $r_{X Y}=0,85$. Setelah diuji signifikansinya dengan menggunakan statistik uji-t diperoleh thitung $=20,98$ dan tabel $=1,65$ karena thitung $>$ ttabel yaitu 20,98 > 1,65 maka tolak Ho. Artinya, korelasi antara kebiasaan belajar siswa dengan hasil belajar matematika adalah signifikan. Karena koefisien korelasi bernilai positif, maka dapat dikatakan bahwa koefisien korelasi antara kebiasaan belajar siswa dengan hasil belajar 
matematika bersifat positif dan signifikan. Hal ini berarti semakin tinggi kebiasaan belajar siswa maka semakin tinggi pula hasil belajar matematika yang dapat dicapai.

Selanjutnya guna mengetahui seberapa besar sumbangan relatif atau kontribusi dari variabel kebiasaan belajar siswa terhadap hasil belajar matematika maka akan dicari koefisien determinasinya. Berdasarkan perhitungan diperoleh nilai koefisien determiasi $(r 2)=0,7225$. Koefisien determinasi ini ditentukan dengan mengkuadratkan nilai koefisien korelasi dan dikalikan dengan $100 \%$. Sehingga kontribusi variabel $\mathrm{X}_{2}$ terhadap Y sebesar 72,25\%. Angka ini berarti sebesar 72,25\% hasil belajar matematika dapat dijelaskan dengan menggunakan variabel kebiasaan belajar siswa, sedangkan $27,75 \%$ dipengaruhi oleh faktor lain. Berdasarkan hasil uji tersebut, dapat disimpulkan bahwa terdapat pengaruh positif kebiasaan belajar siswa terhadap hasil belajar matematika

\section{Pengaruh Motivasi Belajar Siswa (X1) dan Kebiasaan Belajar Siswa (X2) terhadap Hasil}

\section{Belajar Matematika (Y)}

Pengujian hipotesis ketiga dilakukan dengan menggunakan analisis regresi berganda dua prediktor dalam hal ini pengaruh motivasi belajar siswa $\left(\mathrm{X}_{1}\right)$ dan kebiasaan belajar siswa (X2) terhadap satu variabel terikat yaitu hasil belajar matematika (Y). Berdasarkan hasil perhitungan regresi berganda diperoleh nilai konstanta $\alpha=-1,93, b_{1}=1,15$, dan $b_{2}=-0,13$. Dengan demikian model persamaan regresi bergandanya adalah $Y^{\wedge}=-1,93+1,15 X_{1}-$ $0,13 X 2$. Guna mengetahui keberartian dari persamaan tersebut maka dilakukan uji signifikansi dengan menggunakan analisis varians regresi berikut.

Tabel 6. Hasil Anava Untuk Persamaan Regresi $\bar{Y}=1,93+1,15 X_{1}-0,13 X_{2}$

\begin{tabular}{cccccc}
\hline Sumber Varians & JK & db & RJK & $F_{\text {hitung }}$ & $F_{\text {Tabel( } 0,95 ; 2 ; 170)}$ \\
\hline Regresi & 58386,27 & 2 & 29193,14 & 587,27 & 3,05 \\
Residu & 8451,06 & 170 & 49,71 & & \\
Total & & 172 & & & \\
\hline
\end{tabular}

Berdasarkan Tabel 6 pada pengujian signifikansi regresi diperoleh $F_{\text {hitung }}=587,27$ dan $F_{\text {tabel }}=$ 3,05 karena $F_{\text {hitung }}>F_{\text {tabel }}$ yaitu, 587,27 > 3,05 maka tolak Ho. Artinya, persamaan regresi tersebut signifikan dan dapat dipergunakan untuk memprediksi rata-rata $\mathrm{Y}$ jika nilai $\mathrm{X}_{1}$ dan $\mathrm{X}_{2}$ diketahui. Langkah berikutnyasetelah signifikansi persamaan regresi terpenuhi adalah menghitung koefisien korelasi ganda. Berdasarkan hasil perhitungan diperoleh koefisien korelasi ganda $R_{y} .12=0,93$ atau $2 y .12 R=0,87$. Hal ini menunjukkan bahwa $87 \%$ variasi yang 
terjadi pada variabel hasil belajar matematika dapat ditentukan secara bersamasama oleh variabel motivasi dan kebiasaan belajar siswa. Sedangkan 13\% dipengaruhi oleh faktor lain yang tidak dibahas pada penelitian ini.

Guna menjamin kebenaran pengambilan keputusan maka koefisien tersebut diuji signifikansinya dengan uji F. Hasil perhitungan diperoleh $F_{\text {hitung }}=568,85$ dan $F_{\text {tabel }}=3,05$. Karena $F_{\text {hitung }}>F_{\text {tabel }}$ yaitu 568,85 $>$ 3,05 maka tolak Ho. Artinya, koefisien korelasi ganda antara $\mathrm{Y}$ dengan $\mathrm{X}_{1}$ dan $\mathrm{X}_{2}$ signifikan. Hal ini menunjukkan bahwa terdapat pengaruh positif antara motivasi dan kebiasaan belajar siswa secara bersama-sama terhadap hasil belajar matematika. Langkah perhitungan yang dilakukan selanjutnya adalah melakukan uji signifikansi koefisien persamaan regresi ganda yaitu untuk menentukan signifikansi dari masing-masing koefisien $\mathrm{X}_{1}$ dan $\mathrm{X}_{2}$ dengan menggunakan statistik uji-t. Berdasarkan hasil perhitungan, untuk koefisien $\mathrm{X}_{1}$ diperoleh $t_{1}=14,38$ dan $t_{\text {tabel }}$ sebesar 1,65 . Karena $t_{\text {hitung }}>t_{\text {tabel }}$ yaitu 14,38 > 1,65 maka koefisien yang berkaitan dengan $\mathrm{X}_{1}$ adalah signifikan atau koefisien dari $\mathrm{X}_{1}$ tidak dapat diabaikan. Dengan demikian dapat disimpulkan bahwa setiap peningkatan satu unit motivasi belajar siswa maka hasil belajar matematika mengalami peningkatan sebesar 1,15 dengan asumsi bahwa variabel bebas yang lain dari model regresi adalah tetap. Sedangkan untuk koefisien $\mathrm{X}_{2}$ diperoleh thitung $=-2,6$ dan $t_{\text {tabel }}=1,65$. Karena $t$ hitung $<t_{\text {tabel }}$ yaitu, -2,6 < 1,65 maka koefisien yang berkaitan dengan $\mathrm{X}_{2}$ adalah tidak signifikan. Dengan demikian dapat disimpulkan bahwa setiap penurunan satu unit kebiasaan belajar siswa maka hasil belajar matematika mengalami penurunan sebesar 0,13 dengan asumsi bahwa variabel bebas yang lain dari model persamaan regresi adalah tetap.

Langkah perhitungan yang dilakukan selanjutnya adalah menguji korelasi parsial, dari hasil perhitungan diperoleh koefisien korelasi parsial antara $\mathrm{Y}$ dan $\mathrm{X}_{1}$ jika $\mathrm{X}_{2}$ dikontrol (ryl.2) yaitu sebesar 0,55. Hasil pengujian keberartian kedua koefisien parsial diperoleh nilai thitung = 8,54 dan $t_{\text {tabel }}=1,65$ karena thitung $>$ tabel yaitu 8,54 > 1,65 maka tolak Ho. Hal ini dapat diartikan bahwa koefisien korelasi parsial antara $\mathrm{Y}$ dan $\mathrm{X}_{1}$ jika $\mathrm{X}_{2}$ dikontrol adalah signifikan. Dengan kata lain walaupun variabel $\mathrm{X}_{2}$ telah dikontrol, variabel $\mathrm{X}_{1}$ masih memiliki hubungan signifikan dengan $\mathrm{Y}$. Sehingga dapat disimpulkan bahwa dengan mengontrol variabel $\mathrm{X}_{2}$ maka sebesar 0,3025 atau 30,25\% variasi $\mathrm{Y}$ dapat dijelaskan oleh variabel $\mathrm{X}_{1}$. Sedangkan koefisien korelasi parsial antara $\mathrm{Y}$ dan $\mathrm{X}_{2}$ jika $\mathrm{X}_{1}$ dikontrol (ry2.1) yaitu -0,14. Dari hasil pengujian keberartian kedua koefisien parsial diperoleh nilai thitung $=-1,84$ dan tabel $=1,65$ karena thitung $<$ tabel yaitu $-1,84<1,65$ hal ini dapat diartikan bahwa koefisien korelasi parsial 
antara $\mathrm{Y}$ dan $\mathrm{X}_{2}$ jika $\mathrm{X}_{1}$ dikontrol adalah tidak signifikan. Dengan kata lain dengan mengontrol variabel $\mathrm{X}_{1}$ maka hanya sebesar 0,02 atau 2\% variasi $\mathrm{Y}$ dapat dijelaskan oleh variabel $\mathrm{X}_{2}$. Untuk mempermudah melihat urutan atau peringkat keeratan hubungan antara variabel bebas dengan variabel terikat maka disajikan koefisien korelasi parsial pada Tabel 7.

Tabel 7. Peringkat Hubungan Variabel Bebas dan Variabel Terikat

\begin{tabular}{cccccc}
\hline $\begin{array}{c}\text { Koefisien Korelasi } \\
\text { Parsial }\end{array}$ & $\mathbf{n}$ & $\mathbf{d b}$ & $t_{\text {hitung }}$ & $t_{\text {Tabel }(0,95 ; 170)}$ & Peringkat \\
\hline$r_{y 12}=0,55$ & 173 & 170 & 8,54 & & Pertama \\
$r_{y 21}=-0,14$ & 173 & 170 & $-1,84$ & 1,65 & Kedua \\
\hline
\end{tabular}

Tabel $7 \mathrm{di}$ atas menunjukkan bahwa peringkat pertama keeratan hubungan antar variabel bebas dan variabel terikat dimiliki oleh variabel motivasi belajar siswa dan peringkat kedua adalah variabel kebiasaan belajar siswa. Hal ini juga berimplikasi bahwa apabila hasil belajar matematika ingin ditingkatkan maka faktor pertama yang perlu ditingkatkan adalah motivasi belajar siswa kemudian kedua adalah faktor kebiasaan belajar siswa tersebut.

Hasil uji hipotesis pertama menunjukkan bahwa terdapat pengaruh positif motivasi belajar siswa terhadap hasil belajar matematika. Hasil uji hipotesis diperoleh persamaan regresi $Y^{\wedge}=0,04+0,97 X$. Persamaan tersebut dapat digunakan sebagai alat prediksi untuk mengetahui pengaruh motivasi belajar siswa terhadap hasil belajar matematika yaitu setiap peningkatan satu unit motivasi belajar siswa $\left(\mathrm{X}_{1}\right)$ maka hasil belajar matematika mengalami peningkatan sebesar 0,97. Di samping itu berdasarkan hasil pengujian pada hipotesis pertama diperoleh koefisien korelasi sebesar 0,93 sehingga koefisien determinasinya adalah 0,8649. Hal ini berarti $86,49 \%$ variasi nilai hasil belajar matematika ditentukan oleh faktor motivasi belajar siswa. Sedangkan 13,51\% ditentukan oleh faktor-faktor lain yang tidak dibahas pada penelitian ini.

Implikasi dari penelitian ini adalah semakin tinggi motivasi belajar siswa maka semakin dapat meningkatkan hasil belajar matematika. Keberhasilan siswa dalam belajar tidak hanya bergantung pada cara penyajian materi pelajaran dan metode mengajar namun salah satunya dapat pula dipengaruhi oleh motivasi belajar siswa. Hasil penelitian tersebut mendukung pendapat Sardiman (2014) yang mengatakan bahwa untuk belajar sangat diperlukan adanya motivasi. Hasil belajar akan menjadi optimal apabila ada motivasi. Makin 
tepat motivasi yang diberikan, maka akan berhasil pula pelajaran itu. Sejalan dengan pendapat di atas, hasil penelitian yang dilakukan oleh Sriwati (2012) menghasilkan kesimpulan bahwa motivasi belajar siswa berpengaruh positif terhadap hasil belajar matematika. Semakin tinggi motivasi belajar yang dimiliki siswa maka semakin tinggi pula hasil belajar matematika yang didapat. Begitupun sebaliknya jika motivasi belajar siswa rendah maka hasil belajar matematika akan rendah. Sehingga dapat disimpulkan bahwa terdapat pengaruh positif motivasi belajar siswa terhadap hasil belajar matematika.

Hasil uji hipotesis kedua menunjukkan bahwa terdapat pengaruh positif kebiasaan belajar siswa terhadap hasil belajar matematika. Hasil uji hipotesis diperoleh persamaan regresi $Y^{\wedge}=15,99+0,62 X$. Persamaan tersebut dapat digunakan sebagai alat prediksi pengaruh kebiasaan belajar siswa terhadap hasil belajar matematika yaitu setiap peningkatan satu unit kebiasaan belajar siswa $\left(\mathrm{X}_{2}\right)$ maka hasil belajar matematika mengalami peningkatan sebesar 0,62. Di samping itu berdasarkan hasil pengujian pada hipotesis kedua diperoleh koefisien korelasi sebesar 0,85 sehingga koefisien determinasinya adalah 0,7225. Hal ini berarti $72,25 \%$ variasi nilai hasil belajar matematika dipengaruhi oleh faktor kebiasaan belajar siswa sedangkan $27,75 \%$ ditentukan oleh faktor-faktor lain yang tidak dibahas pada penelitian ini.

Implikasi dari penelitian ini adalah semakin baik kebiasaan belajar siswa maka semakin dapat meningkatkan hasil belajar matematika. Dengan kata lain hasil belajar matematika dapat dipengaruhi oleh kebiasaan belajar siswa. Sejalan dengan pendapat di atas, penelitian yang dilakukan oleh Azainil (2014) bahwa terdapat pengaruh yang signifikan antara motivasi dan kebiasaan belajar terhadap hasil belajar matematika. Kebiasaan belajar siswa sangat berperan penting dalam pencapaian hasil belajar mateatika. Dengan kebiasaan belajar yang baik maka siswa akan mendapatkan hasil belajar yang baik. Begitupun sebaliknya jika kebiasaan belajar siswa tidak baik maka hasil belajar yang didapat siswa tersebut akan rendah. Sehingga dapat disimpulkan bahwa terdapat pengaruh positif kebiasaan belajar siswa terhadap hasil belajar matematika

Hasil uji hipotesis ketiga menunjukkan bahwa terdapat pengaruh positif antara motivasi belajar dan kebiasaan belajar siswa secara bersama-sama terhadap hasil belajar matematika. Hasil uji hipotesis diperoleh persamaan regresi $Y^{\wedge}=-1,93+1,15 X_{1}-0,13 X_{2}$. Persamaan memenuhi kriteria sebagai alat untuk memprediksi hasil belajar matematika atas motivasi dan kebiasaan belajar siswa. Hal ini ditunjukkan bahwa setiap penambahan satu unit 
nilai motivasi belajar siswa (1) akan diikuti oleh peingkatan 1,15 unit hasil belajar matematika dan setiap pengurangan satu unit nilai kebiasaan belajar siswa $\left(\mathrm{X}_{2}\right)$ akan diikuti oleh penurunan sebesar 0,13 unit nilai hasil belajar matematika. Di samping itu berdasarkan hasil pengujian pada hipotesis ketiga diperoleh koefisien korelasi ganda sebesar 0,93 sehingga koefisien determinasinya adalah 0,87. Hal ini berarti $87 \%$ variasi nilai hasil belajar matematika dapat ditentukan secara bersama-sama oleh faktor motivasi dan kebiasaan belajar siswa sedangkan $13 \%$ ditentukan oleh faktor-faktor lain yang tidak dibahas pada penelitian ini.

Implikasi dari penelitian ini adalah semakin tinggi motivasi belajar siswa dan semakin baik kebiasaan belajar siswa, maka semakin dapat meningkatkan hasil belajar matematika. Penelitian ini didukung oleh pendapat Thabrany (1993) yang menyatakan bahwa motivasi dan kebiasaan belajar merupakan dua faktor yang saling berkaitan satu sama lain. Seorang siswa yang memiliki motivasi tinggi cenderung melakukan kebiasaan belajar yang baik khususnya dalam pelajaran matematika, akan memberikan peluang besar untuk memperoleh nilai yang tinggi dari hasil belajarnya. Dengan motivasi belajar yang tinggi dan kebiasaan belajar yang baik maka siswa akan mendapatkan hasil belajar yang baik. Sehingga, dapat disimpulkan bahwa terdapat pengaruh positif motivasi dan kebiasaan belajar siswa secara bersama-sama terhadap hasil belajar matematika.

\section{KESIMPULAN}

Berdasarkan penelitian yang dilakukan serta hasil pengolahan data maka dapat ditarik kesimpulan sebagai berikut.

1. Terdapat pengaruh positif motivasi belajar siswa terhadap hasil belajar matematika.

2. Terdapat pengaruh positif kebiasaan belajar siswa terhadap hasil belajar matematika.

3. Terdapat pengaruh positif antara motivasi dan kebiasaan belajar siswa secara bersamasama terhadap hasil belajar matematika.

\section{UCAPAN TERIMAKASIH}

Terimakasih kepada kepala sekolah SMP Negeri 1 Sindang Kabupaten Indramayu yang telah memberi ijin dan terimakasih kepada guru matematika yang telah membantu dalam pelaksanaan penelitian ini. 


\section{DAFTAR PUSTAKA}

Arikunto, S. (2012). Prosedur Penelitian: Suatu Pendekatan Praktik (Edisi Revisi 2010). Jakarta: Rineka Cipta.

Azainil. (2014). Pengaruh Motivasi Belajar dan Kebiasaan Belajar terhadap Hasil Belajar Matematika Siswa SMPN di Kecamatan Samarinda Utara. Skripsi Universitas Mulawarman Samarinda. 29 Januari 2015. http://repository.uks.edu/handle/123456789/4634.

Effendi, S \& Tukiran. (2012). Metode Penelitian Survei. Jakarta: LP3ES.

Faisal, S. (2007). Format-Format Penelitian Sosial. Jakarta: Raja Grafindo Persada.

Nazir, M. (2011). Metode Penelitian. Bogor: Ghalia Indonesia.

Sadirman, A.M. (2014). Interaksi dan Motivasi Belajar Mengajar. Edisi 1 cetakan ke-22. Jakarta: Rajawali Pers.

Siregar, E \& Nara, H. (2014). Teori Belajar dan Pembelajaran. Cetakan ke-3. Bogor: Ghalia Indonesia.

Soetopo, H \& Soemanto, W. (1988). Kepemimpinan dan Supervisi Pendidikan. Jakarta: Bumi Aksara.

Sriwati. (2012). Pengaruh Motivasi Belajar terhadap Hasil Belajar Matematika Siswa Kelas XI SMA Bukit Barisan Padang. 2 Februari 2015. http://ejurnal.bunghatta.ac.id/index.php?journal=JFKIP\&page=article \& op=view\&path\%5B \%5D=798.

Sugiyono. (2012). Metode penelitian pendidikan, pendekatan kuantitatif, kualitatif, dan $R \&$ $D$. Bandung: Alfabeta.

Thabrany. (1993). Pengaruh Cara Belajar. 3 Februari 2015. https://skripsistikes.files.wordpress.com. 